\title{
EFEKTIVITAS PROSES PEMBELAJARAN LURING PESERTA DIDIK YANG TINGGAL DI ASRAMA DAN DARING BAGI PESERTA DIDIK DI LUAR ASRAMA TERHADAP HASIL BELAJAR PJOK
}

\author{
Ade Mikael Ardhana Ketaren' I Nyoman Kanca ${ }^{2}$ \\ Kadek Yogi Parta Lesmana ${ }^{3}$ \\ 1,2,3 Prodi Pendidikan Jasmani Kesehatan dan Rekreasi, \\ Universitas Pendidikan Ganesha \\ Singaraja, Indonesia \\ e-mail: mikaelketaren@gmail.com kanca.nyoman@undiksha.ac.id \\ yogi.parta@undiksha.ac.id
}

\begin{abstract}
ABSTRAK
Penelitian ini bertujuan untuk mengetahui efektivitas pembelajaran PJOK yang dilaksanakan di SMA Swasta Santa Maria Kabanjahe dimana pelaksanaan proses belajar mengajar dilaksanakan secara tatap muka bagi peserta didik di asrama dan pembelajaran secara jarak jauh bagi peserta didik yang belajar dari rumah dalam situasi pandemi covid-19 dan melihat hasil pembelajaran yang dilakukan secara offline atau online. Penelitian ini merupakan penelitian deskriptif kualitatif, yang menggambarkan bagaimana keterlaksanaan pembelajaran PJOK baik secara tatap muka dan juga secara jarak jauh yang dijabarkan dari hasil belajar peserta didik dalam satu semester yaitu semester ganjil tahun 2020/2021.Subjek dalam penelitian ini diambil dari kelas X IPA 1 dan X IPA 2, dengan rincian peserta didik kelas X IPA 1 berjumlah 40 orang dan peserta didik kelas X IPA 2 berjumlah 40 orang sehingga jumlah sampel yang digunakan dalam penelitian ini berjumlah 80 orang.Teknik pengumpulan data yang digunakan yaitu observasi, wawancara dan dokumentasi. Dari teknik analisis data yang dilakukan pada hasil belajar peserta didik maka diperoleh nilai peserta didik kelas X IPA 1 dengan predikat $A$ (sangat baik) $=17$ orang, $B$ (baik) $=18$ orang, $C$ (cukup) $=3$ orang, $D$ (kurang) $=0$, sedangkan klasifikasi kelas X IPA 2 yakni predikat $A$ (sangat baik) $=13$ orang, $B$ (baik) $=25$ orang, $C$ (cukup) $=5$ orang $D$ (kurang) $=1$ orang. Dari pemaparan hasil belajar peserta didik maka diketahui efektivitas pembelajaran yang dilakukan secara luring lebih efektif dibandingkan pembelajaran yang di lakukan secara daring
\end{abstract}

Kata Kunci: efektivitas, pembelajaran daring dan luring, hasil belajar.

\begin{abstract}
This study aims to determine the effectiveness of PJOK learning that be implemented at senior high school of Santa Maria, Karo District where the implementation of the teach and learn process is carried out face-to-face for students in dormitory and distance learning for students who study at home during COVID-19 pandemic and see the learning outcomes be performed offline or online. The experimental design was used qualitative descriptive method, which represents how the implementation of face-to-face and remote PJOK learning was described from the learning outcomes of students in the odd semester of 2020/2021. Subjects were taken from class X IPA 1 and XIPA 2, students in class X IPA 1 amounted to 40 people and students in class X IPA 2 amounted to 40 people so that the number of samples used in this study amounted to 80 people. Data collection techniques used are observation, interview and documentation. From the data analysis technique carried out on student learning outcomes, the grade XIPA 1 students obtained with the predicate $A$ $($ very good $)=17$ people, $B$ (good) $=18$ people, $C$ (enough) $=3, D$ (less) 0 , while the class $X I P A 2$ classification is $A$ (very good) $=13$ people, $B$ (good) $=25$ people, $C$ (enough) $=5$ people $D$ (less) $=1$ person. From the presentation of student learning outcomes, it is known that the effectiveness of learning that is carried out offline is more effective than learning that is done online.
\end{abstract}

Keywords: effectiveness, online and offline learning, learning outcomes. 


\section{PENDAHULUAN}

Proses pembelajaran adalah suatu proses yang melibatkan interaksi antara peserta didik dan guru maupun antar guru dengan peserta didik. Dimana dengan adanya interaksi ini diharapkan peserta didik dapat memperoleh pemahaman apa yang diberikan dalam proses belajar mengajar. Menurut Munif Chatib (2014) mengatakan bahwa pembelajaran itu adalah transfer ilmu dua arah antara guru sebagai pemberi informasi dan peserta didik menjadi penerima informasi. Dan terjadinya komunikasi antara satu dengan yang lain untuk menuju suatu tujuan tertentu. Namun pada saat sekarang ini kita dihadapkan dengan situasi dan kondisi yang memaksa kita untuk melakukan proses pembelajaran secara jarak jauh ataupun virtual karena pandemi covid-19. Pandemi covid-19 ini memang seperti sebuah tantangan baru bagi kita dalam berprilaku hidup karena mengubah perilaku hidup kita sebagai mahluk hidup dan juga mahluk sosial. Bahkan pandemi ini berdampak kedalam sistem pendidikan yang ada di Indonesia.

PJOK merupakan singkatan dari pendidikan jasmani olahraga dan kesehatan yakkni mata pelajaran yang memiliki karakteristik mengutamakan ranah psikomotorik, tetapi tidak menyampingkan ranah kognitif, dan afektif. Psikomotorik merupakan ranah yang berkaitan dengan aspek-aspek keterampilan yang melibatkan fungsi sistem saraf dan otot dan berfungsi praktis, kognitif adalah ranah yang berkaitan dengan ilmu pengetahuan ataupun merupakan suatu teori dan afektif merupakan ranah yang berkaitan dengan emosi seseorang dan dengan caranya bertingkah laku. Dalam proses pembelajaran PJOK secara langsung, maka tidak akan sulit untuk menyampaikannya kepada peserta didik namun ini adalah tantangan baru bagaimana menyampaikan ketiga karakteristik PJOK tersebut kepada peserta didik dengan pembelajaran sistem online apakah mereka dapat menerima pembelajaran PJOK secara baik dan mengerti dan bagaimana responnya terhadap pembelajaran PJOK yang diberikan secara online. Menurut Rosdiani (2013) mengungkapkan proses pembelajaran pendidikan jasmani yakni memanfaatkan aktivitas jasmani yang direncanakan secara sistematis bertujuan untuk mengembangkan dan meningkatkan individu secara organik, perseptual, kognitif, dan emosional dalam kerangka sistem pendidikan nasional. Menurut Mulyanto (2014) juga megungkapkan bahwa proses pembelajaran pendidikan jasmani adalah proses belajar untuk bergerak dan belajar melalui gerak.

Sebelum pandemi covid-19 maka pembelajan luring atau pembelajaran tatap muka yang berlangsung di setiap jenjang sekolah namun dikarenakan situasi dan kondisi saat ini belum memungkinkan untuk melakukan pembelajaran secara tatap muka sehingga pembelajaran secara daring adalah pilihan yang paling tepat dalam menanggulanginya. Menurut Santyasa (2005) juga mengatakan pembelajaran langsung memiliki dua faktor yang mendukungnya yaitu desain dan evaluasi pembelajaran yang dilaksanakan dengan hubungan timbal balik antara guru dengan peserta didik. Pembelajaran yang berbasis daring merupakan sebuah sistem pembelajaran yang menggunakan aplikasi sebagai teknologi informasi yang diterapkan dalam bentuk virtual learning. Menurut Yuliana, dkk (2020) pembelajaran daring merupakan pembelajaran yang menggunakan jaringan internet dengan aksebilitas, konektivitas, fleksibelitas, dan kemamuan untuk memunculkan berbagai jenis interaksi pembelajaran. Menurut Kuantarto, E. dkk (2020) menyatakan pembelajaran daring adalah pembelajaran yang mampu mempertemukan dosen dan mahasiswa untuk melaksanakan interaksi dengan bantuan internet. Menjelaskan bahwa pembelajaran daring adalah pilihan terbaik yang dapat dilaksanakan dalam proses pembelajaran pada masa pandemi covid19. Menurut Pujiasih (2020 menyatakan dalam menerapkan pembelajaran daring guru harus mampu menggunakan teknologi internet yang dapat mempermudah guru dalam memberikan pembelajaran dan memudahkan siswa 
dalam menerima pembelajaran. Jadi dari beberapa pengertian di atas dapat disimpulkan bahwa pembelajaran daring merupakan pembelajaran jarak jauh, yang mampu mempertemukan guru dan peserta didik untuk melakukan suatu proses interaksi dengan bantuan jaringan internet. Jadi pada proses pembelajaran daring ini sangat diperlukan media yang dapat digunakan untuk menunjang suatu proses pembelajaran agar proses pembelajaran dapat berjalan secara efektif.

Namun ada hal yang menarik dari sebuah gebrakan yang dilakukan oleh SMA Swasta Santa Maria Kabanjahe dalam menyikapi proses pelaksanaan belajar mengajar dalam situasi pandemi covid-19. SMA Swasta Santa Maria Kabanjahe merupakan salah satu sekolah yang berlokasi di kota Kabanjahe kabupaten Karo provinsi Sumatera Utara, dan merupakan salah satu SMA yang memiliki Asrama baik putra ataupun putri, sehingga sekolah ini memiliki banyak peserta didik yang berasal dari luar kota ataupun desa jauh dari kota Kabanjahe, oleh karena itu mereka tetap untuk memilih tinggal di Asrama agar tetap dapat mengikuti pembelajaran dikarenakan di tempat mereka tinggal belum terjangkau oleh sinyal dan jaringan dan ada juga yang belum memiliki handphone. Akhirnya sekolah mengambil sebuah keputusan agar peserta didik yang berada di dalam lokasi Asrama tetap dapat melakukan pembelajaran secara langsung karena mereka tetap tinggal di Asrama dan tidak bertemu dengan orang yang sembarangan dan berasal dari luar. Di SMA Santa Maria Kabanjahe ada dua proses pembelajaran yang berlangsung yakni sistem pembelajaran luring bagi peserta didik yang belajar di asrama sekolah dan sistem pembelajaran daring bagi peserta didik yang belajar dari rumah mereka masing-masing. Oleh karena itu timbul permasalahan dan juga pertanyaan baik dari orang tua, guru dan juga orang banyak yang mempertanyakan pembelajaran apa yang paling efektif dilaksanakan. Ketika hanya menjadi sebuah argumen dan tidak ada bukti nyata maka tidak dapat ditarik sebuah kesimpulan dan hasil yang akurat.

Berdasarkan permasalahan di atas maka peneliti berkeinginan untuk mengangkat sebuah penelitian yang berjudul: "Efektivitas Proses Pembelajaran Luring Peserta Didik Yang Tinggal Di Asrama Dan Daring Bagi Peserta Didik Di Luar Asrama Terhadap Hasil Belajar PJOK Kelas X IPA SMA Swasta Santa Maria Kabanjahe Tahun Pelajaran 2020/2021."

Merujuk dari permasalahan diatas maka dapat diuraikan rumusan masalah sebagai berikut:

1. Bagaimanakah efektvitas proses pembelajaran luring peserta didik yang tinggal di asrama terhadap hasil belajar PJOK kelas X IPA SMA Swasta Santa Maria Kabanjahe Tahun pelajaran 2020/2021?

2. Bagaimanakah efektvitas proses pembelajaran daring peserta didik yang tinggal di luar asrama terhadap hasil belajar PJOK kelas X IPA SMA Swasta Santa Maria Kabanjahe Tahun pelajaran 2020/2021?

3. Apakah ada perbedaan hasil belajar PJOK antara proses pembelajaran luring dan daring peserta didik kelas X IPA SMA Swasta Santa Maria Kabanjahe Tahun pelajaran 2020/2021?

Adapun tujuan dari penelitian ini antara lain:

1. Untuk mengetahui efektvitas proses pembelajaran luring peserta didik yang tinggal di asrama terhadap hasil belajar PJOK kelas X IPA SMA Swasta Santa Maria Kabanjahe Tahun pelajaran 2020/2021

2. Untuk mengetahui efektvitas proses pembelajaran daring peserta didik yang tinggal di luar asrama terhadap hasil belajar PJOK kelas X IPA SMA Swasta Santa Maria Kabanjahe Tahun pelajaran 2020/2021.

3. Untuk mengetahui perbedaan hasil belajar PJOK antara proses pembelajaran luring dan daring peserta didik kelas X IPA SMA Swasta Santa Maria Kabanjahe Tahun Pelajaran 2020/2021 
Pada penelitian ini nantinya akan melihat efektivitas pembelajaran PJOK yang dilihat dari hasil belajar peserta didik selama satu semester pada anak kelas $X$ IPA yang berada di SMA Santa Maria Kabanjahe. Menurut Popham (2003) mengatakan efektivitas proses pembelajaran seharusnya ditinjau dari hubungan dari hubungan guru yang mengajar kelompok peserta didik tertentu, didalam situasi tertentu dalam usaha mencapai tujuan-tujuan intruksional tertentu. Menurut Dunne (1996), efektivitas pembelajaran memiliki dua karakteristik. Karakteristik pertama adalah "memudahkan murid belajar" sesuatu yang bermanfaat, seperti fakta, keterampilan, nilai konsep atau sesuatu hasil belajar yang di inginkan. Kedua, bahwa keterampilan diikuti oleh mereka yang berkompeten menilai, seperti guru, pengawas, tutor atau murid sendiri. Menurut Pardomuan Sinambela (2008) pembelajaran di katakan efektif apabila mencapai sasaran yang di inginkan, baik dari segi tujuan pembelajaran maupun prestasi siswa yang maksimal. Berdasarkan beberapa pengertian yang telah diuraikan di atas dapat di simpulkan bahwa efektivitas pembelajaran merupakan tingkat keberhasilan yang di capai dalam proses pembelajaran dengan menggunakan metode tertentu sesuai dengan pembelajaran yang telah di rencanakan.

Menurut Dimyati dan Mudjiono (2006:3) mengungkapkan dengan berakhirnya suatu proses belajar, maka siswa memperoleh suatu hasil belajar. Hasil belajar merupakan hasil dari suatu interaksi tindak belajar dan tindak mengajar. Menurut Dimyati dan Mudjiono (2006:26) mengkategorikan hasil belajar dapat diperoleh dari jenis perilaku dan kemampuan internal akibat belajar, antara lain: a) ranah kognitif, b) ranah afektif, dan c) ranah psikomotor. Berdasarkan beberapa pengertian hasil belajar dar beberapa ahli diatas maka dapat disimpulkan hasil belajar adalah produk ataupun titik akhir dari proses pembelajaran antara guru dengan peserta didik. Oleh karena itu hasil belajar peserta didik selama satu semester yakni semester ganjil maka akan diketahui apakah terdapat perbedaan hasil belajar antara peserta didik yang belajar secara luring dengan peserta didik yang belajar secara daring di kelas X IPA SMA Swasta Santa Maria Kabanjahe.

\section{METODE}

Metode penelitian yang digunakan dalam penelitian ini adalah metode penelitian kualitatif atau naturalistik karena dilakukan pada kondisi yang alamiah yang menggunakan fakta-fakta yang ada dilapangan sebagaimana adanya. Menurut Sugiyono (2013) mengemukakan bahwa metode penelitian kualitatif adalah metode penelitian yang digunakan untuk meneliti pada kondisi obyek yang alamiah, dimana peneliti adalah sebagai instrumen kunci, teknik pengumpulan data dilakukan secara triangulasi (gabungan), analisis data bersifat induktif, dan hasil penelitian kualitatif le

bih menekankan makna daripada generalisasi. Metode kualitatif menurut Creswell (1998) adalah suatu proses penelitian dan pemahaman yang berdasarkan pada metodologi yang menyelidiki suatu fenomena sosial dan membuat suatu gambaran kompleks, meneliti kata-kata, laporan terinci dari pandangan responden dan melakukan studi pada situasi yang alami.

Dan penelitian ini dilakukan dengan kegiatan, yaitu wawancara pengamatan atau pedoman observasi, serta pedoman dokumentasi. Dan data hasil belajar peserta didik di peroleh melalui test hasil belajar (hasil laporan nilai semester ganjil).

Di dalam melakukan penelitian, maka peneliti harus memiliki populasi dimana pengertian" populasi adalah keseluruhan atau himpunan objek dengan ciri yang sama" (Kanca,2010:19). Populasi dalam penelitian ini adalah peserta didik kelas X di SMA Santa Maria Kabanjahe yang terdiri dari 5 kelas yaitu 
Tabel 3.1

Distribusi populasi kelas X SMA Santa Maria Kabanjahe

\begin{tabular}{lll}
\hline No & Kelas & Peserta Didik (orang) \\
\hline 1 & X IPA 1 & 40 \\
\hline 2 & X IPA 2 & 40 \\
\hline 3 & X IPA 3 & 39 \\
\hline 4 & X IPS 1 & 41 \\
\hline 5 & X IPS 2 & 42 \\
\hline Jumlah & & 202 \\
\hline
\end{tabular}

Sampel adalah himpunan bagian (sebagian) populasi yang diambil secara representative dari populasi" Kanca (2010:20). Sampel penelitian diambil dengan menggunakan teknik simple random sampling. Teknik simple random sampling yaitu teknik pengambilan sampel atau elemen secara acak sederhana, dimana setiap elemen mempunyai kesempatan yang sama untuk dipilih menjadi anggota sampel, dalam pengambilan sampel yang dirandom adalah kelas. "Pengambilan sampel dapat dilakukan dengan bantuan atau melalui lotre (undian) bilangan random" Kanca, (2010:24) Dari hasil random sederrhana diperoleh bahwa kelas X IPA 1 dan kelas X IPA 2, dimana kelas $X$ IPA 1 adalah kelas yang pembelajarannnya dengan sistem pembelajaran tatap muka (luring) dan $X$ IPA 2 adalah kelas yang pembelajarannya dengan sistem pembelajaran secara virtual (daring)

Tabel.2

Sampel penelitian pada masing-masing sistem pembelajaran

\begin{tabular}{llll}
\hline NO & Sampel & Sistem Pembelajaran & Peserta Didik \\
\hline 1 & X IPA 1 & SecaraTatap Muka (luring) & 40 \\
\hline 2 & X IPA 2 & Secara Virtual (daring) & 40 \\
\hline Jumlah Total & & 80 \\
\hline
\end{tabular}

\section{HASIL DAN PEMBAHASAN}

Hasil dari penelitian ini diperoleh dari hasil observasi yang dilakukan terlebih dahulu oleh peneliti agar mengetahui apa masalah begitu juga situasi dan kondisi yang dialami sekolah, berikutnya adalah wawancara yang mendalam dengan informan yakni kepala sekolah dan juga guru pjok SMA Swasta Santa Maria Kabanjahe, dan yang terakhir dilakukan dengan dokumentasi untuk mengetahui keadaaan yang terjadi di lapangan begitu juga data yang diperlukan sebagai pendukung dalam penelitian ini. Dimana penelitian ini berfokus untuk mengetahui apakah pembelajaran secara tatap muka dapat lebih efektif dibandingkan dengan pembelajaran jarak jauh yang dilakukan pada peserta didik kelas $X$ SMA Swasta Santa Maria
Kabanjahe melalui hasil belajar semester ganjil tahun pelajaran 2020/2021.

SMA Swasta Santa Maria Kabanjahe merupakan salah satu SMA yang berada di kota Kabanjahe Kabupaten Karo Provinsi Sumatera Utara. Dimana Sekolah ini dalam lindungan Santa Maria yang dikelola oleh Yayasan Setia Medan yang di dirikan pada 21 Juli 2003. Hal yang paling menarik dari sekolah ini dan membuat banyak orang tua berkeinginan anaknya sekolah di sini, karena sekolah ini menyediakan asrama baik bagi putra maupun putri sehingga peserta didik yang berasal dari desa yang jauh juga belum terdapat SMA di tempat mereka tinggal dapat melanjutkan sekolah di sini dan untuk tempat tinggal sudah disediakan asrama dan orang tua tidak perlu lagi khawatir karena asrama bukan hanya 
sebagai tempat mereka tinggal namun juga mental dan kepribadian peserta didik ditempah untuk menjadi lebih baik lagi. Dan dimana sekolah ini menerapkan prinsip SFD bagi seluruh warga sekolah yaitu semangat fraternitas dina yaitu menerapkan senyum, salam dan sapa ketika bertemu dan berpapasan dimana saja dengan warga sekolah dengan tujuan agar semakin mendalam rasa kasih sayang dan saling mengasihi baik antara guru dengan guru, guru dengan peserta didik dan antara peserta didik.

Tenaga pendidik ataupun guru yang mengajar di SMA Swasta Santa Maria juga sudah di seleksi dan sesuai dengan kriteria yang ditentukan oleh yayasan sekolah yang ahli di bidang mata pelajaran nya masing-masing. Berikut adalah jumlah guru yang ada di SMA Swasta Santa Maria Kabanjahe antara lain:

Tabel.3

Daftar Guru di SMA Santa Maria Kabanjahe

\begin{tabular}{lll} 
No. & Guru & Jumlah \\
\hline 1 & Laki-Laki & 18 orang \\
\hline 2 & Perempuan & 16 orang \\
\hline Jumlah & & 34 orang
\end{tabular}

Peserta didik SMA Swasta Santa Maria Kabanjahe berasal dari berbagai daerah baik ada yang diluar kecamatan, kabupaten, kota dan bahkan ada yang dari luar provinsi sumatera utara. Berikut adalah rincian jumlah peserta didik kelas X SMA Swasta Santa Maria antara lain sebagai berikut:

Tabel.4

Peserta Didik Kelas X SMA Santa Maria Kabanjahe

\begin{tabular}{lll}
\hline No & Kelas & Peserta Didik (orang) \\
\hline 1 & X IPA 1 & 40 \\
\hline 2 & X IPA 2 & 40 \\
\hline 3 & X IPA 3 & 39 \\
\hline 4 & X IPS 1 & 41 \\
\hline 5 & X IPS 2 & 42 \\
\hline Jumlah & & 202 \\
\hline
\end{tabular}

Proses belajar mengajar yang biasanya dilaksanakan secara tatap muka namun keadaan membuat proses belajar mengajar dilaksanakan secara jarak jauh. Begitu juga pembelajaran yang berlangsung di SMA Swasta Santa Maria, di mana peneliti melaksanakan PPL disana, namun ada hal yang menarik karena peneliti tetap mendapat pengalaman mengajar secara langsung karena sekolah ini tetap melaksanakan proses pembelajaran secara tatap muka terhadap peserta didik yang ada di asrama dan pembelajaran secara jarak jauh terhadap peserta didik yang tidak tinggal di asrama. Berikut adalah sumber informan yang peneliti dapatkan melalui wawancara dengan kepala sekolah dan guru pjok SMA Swasta Santa Maria Kabanjahe.

Pelaksanaan proses wawancara dengan bapak Waji Ginting Peneliti merasa tertarik dan bertanya apa yang menjadi alasan dan faktor terkuat sehingga sekolah tetap melaksanakan proses pembelajaran secara tatap muka di tengah pandemi covid-19 dan beliau mengatakan: 
"Sekolah kita ini peserta didiknya bukan hanya dari kota kabanjahe atau berastagi saja namun banyak yang dari luar kota dan juga dari daerah desa karena kita memiliki asrama baik putra maupun putri, sehingga setelah berunding dengan orang tua dan guru mereka mengusulkan agar anak mereka tetap dapat melakukan pembelajaran secara tatap muka dengan beberapa pertimbangan yaitu lokasi tempat tinggal yang belum terjangkau sinyal, kepemilikan smartphone, dan juga keterbatasan ekonomi orang tua. Sehingga diambil suatu keputusan tetap dilaksanakan pembelajaran tatap muka namun dengan syarat peserta didik selama satu semester harus tetap berada di asrama dan tidak dapat pulang ke rumah mereka, agar menjaga kondisi dan juga situasi sekarang ini dan pada saaat melakukan pembelajaran tetap mematuhi protokol kesehatan seperti memakai masker dan hand sanitizer begitu juga menjaga jarak saat proses belajar mengajar berlangsung".

Peneliti merasa semakin tertarik karena pembelajaran PJOK yang dominan dengan aktivitas fisik dan bagaimana pelaksanaannya di situasi pandemi covid19, oleh karena ini peneliti melakukan wawancara kembali dengan salah satu informan yaitu bapak Agus Suheri Edi Sembiring selaku guru olahraga di sekolah mengatakan:

"Jadi proses belajar mengajar di sini yaitu kita mengajar secara tatap muka kepada anak asrama dan mengajar dengan memberikan video pembelajaran kepada peserta didik yang belajar dari rumah, dan proses nya berlangsung di dalam aplikasi google classroom. Jadi begitu juga dalam pembelajaran PJOK yang berlangsung di sekolah kita ini yaitu dengan memberikan video materi bahan ajar melalui video kita yang mengajar yang diupload ke dalam aplikasi you tube kemudian kita bagikan kepada peserta didik. Ya kita harus sebisa dan sekreatif mungkin dalam membuat video agar peserta didik tidak bosan dengan pembelajaran kita"

Berdasarkan hasil wawancara diatas melalui dua informan yaitu kepala sekolah dan juga guru PJOK SMA Swasta Santa Maria maka dapat disimpulkan bahwa proses belajar mengajar tetap dilaksanakan di SMA Swasta Santa Maria Kabanjahe meskipun dalam situasi pandemi covid-19 dengan dua pelaksanaan pembelajaran yaitu peserta didik yang berada di asrama proses belajar mengajat tetap dilakukan secara tatap muka dan peserta didik yang belajar dari rumah dilaksanakan pembelajaran secara jarak jauh melalui video pembelajaran yang di bagikan melalui aplikasi youtube dan google clasroom. Dimana keputusan ini diambil oleh pimpinan berdasarkan hasil diskusi dan musyawarah antara guru dan juga orang tua yang juga telah di setujui oleh pihak yayasan dan juga dinas pendidikan dengan memperhatikan protokol kesehatan.

\section{Deskripsi Hasil Belajar Peserta Didik Kelas X IPA SMA Santa Maria}

Pemaparan hasil belajar peserta didik kelas X IPA 1 dan X IPA 2 dimana kelas berikut lah yang menjadi sampel peneliti dimana kelas X IPA 1 adalah kelas yang peserta didiknya proses pelaksanaan belajar mengajarnya dilakukan secara tatap muka dan kelas X IPA 2 proses belajar mengajar dilakukan secara jarak jauh. Untuk mengetahui tingkat keefektifan belajar peserta didik maka peneliti memakai standard Kriteria Ketuntasan Minimal yang sumbernya berasal dari SMA Swasta Santa Maria Kabanjahe itu sendiri.

Tabel 5

Kriteria Ketuntasan Minimal Peserta Didik

\begin{tabular}{cccc}
\hline Interval Nilai & Predikat & Keterangan & Ketuntasan \\
\hline $86-100$ & A & Sangat Baik & Tuntas \\
\hline $80-85$ & B & Baik & Tuntas \\
\hline $70-79$ & C & Cukup & Tuntas \\
\hline$<70$ & D & Kurang & Tidak Tuntas \\
\hline
\end{tabular}


Sumber : (data KKM kelas X SMA Santa Maria Kabanjahe 2019/2020)

Berikut adalah pemaparan tabel hasil belajar peserta didik dengan keterangan jumlah peserta didik yang sama, klasifikasi predikat hasil belajar peserta didik yang belajar dengan sistem pembelajaran luring lebih unggul dari hasil belajar peserta didik yang belajar dengan sistem pembelajaran daring dengan keterangan sebagai berikut:

Tabel 6

Predikat Jumlah Peserta Didik

\begin{tabular}{cccc} 
No. & Predikat & $\begin{array}{c}\text { Pembelajaran } \\
\text { Tatap Muka }\end{array}$ & $\begin{array}{c}\text { Pembelajaran } \\
\text { Jarak Jauh }\end{array}$ \\
\hline 1 & A( Sangat Baik) & 17 & 13 \\
\hline 2 & B (Baik) & 18 & 21 \\
\hline 3 & C (Cukup) & 3 & 5 \\
\hline 4 & D (Kurang) & - & 1 \\
\hline & Jumlah & 40 orang & 40 orang \\
\hline
\end{tabular}

Pemaparan tentang hasil belajar peserta didik yang proses belajar mengajar dilakukan secara luring yang berada di asrama mengungkapkan bahwa pembelajaran secara keseluruhan dapat di ikuti oleh peserta didik karena dari keseluruhan jumlah peserta didik semua masuk dalam kategori tuntas, dan juga dengan predikat prestasi antara lainnya peserta didik yang mendapat predikat A (sangat baik) berjumlah 17 orang, peserta didik yang mendapat predikat B (baik) berjumlah 18 orang, berikutnya peserta didik yang mendapat predikat C (cukup) yakni berjumlah 3 orang dan dari keterangan tabel diatas tidak ada peserta didik yang mendapat predikat D (tidak lulus).

Pemaparan tentang hasil belajar peserta didik dimana proses belajar mengajar dilakukan secara daring terhadap peserta didik yang belajar dari rumah mengungkapkan bahwa secara umum peserta didik dapat mengikuti pembelajaran dengan baik namun ada 1 orang peserta didik yang berhenti sekolah sehingga dari angka keseluruhan peserta didik yang berjumlah 40 orang tersisa 39 orang peserta didik yang masih aktif dalam proses belajar mengajar. Adapun klasifikasi peserta didik berdasarkan hasil belajarnya antara lainnya peserta didik yang mendapat predikat $A$ (sangat baik) berjumlah 13 orang, peserta didik yang mendapat predikat $B$ (baik) berjumlah 21 orang, berikutnya peserta didik yang mendapat predikat $C$ berjumlah 5 orang dan peserta didik yang mendapat predikat $\mathrm{D}$ ada berjumlah 1 orang karena peserta didik tersebut berhenti dari sekolah. Secara umum pembelajaran yang berlangsung secara jarak jauh sudah berlangsung dengan baik karena proses pengawasan yang minim dilakukan dan tidak dapat langsung di kontrol oleh guru namun tetap dapat berjalan dengan baik dan hanya 1 orang peserta didik yang memilih untuk berhenti dengan alasan tertentu.

\section{PEMBAHASAN}

Penelitian mengungkapkan bahwa bagaimana efektivitas proses belajar mengajar yang ada di kelas X IPA SMA Swasta Santa Maria Kabanjahe, karena dalam situasi pandemi covid-19 sekolah ini tetap dapat melaksanakan proses pembelajaran secara tatap muka untuk peserta didik yang tinggal di asrama dan pembelajaran secara jarak jauh bagi peserta didik yang belajar dari rumah. maka jawaban terhadap rumusan masalah dapat peneliti jabarkan sebagai berikut:

1. Proses pelaksanaan pembelajaran secara tatap muka atapun luring yang berlangsung pada peserta didik kelas $X$ IPA SMA Santa Maria Kabanjahe yang 
berada di asrama berlangsung dengan efektif. Seperti yang disampaikan oleh Rusman (2021:21) pembelajaran tatap muka (face to face) yaitu seperangkat tindakan secara terencana berdasarkan kaidah-kaidah pembelajaran yang berupa proses interaksi antara peserta didik, materi pembelajaran, guru, dan lingkungan sehingga guru lebih mudah untuk mengevaluasi sikap siswa. Dengan hasil belajar yang menunjukkan pembelajaran luring juga lebih efektif dibandingkan dengan pembelajaran daring dan temuan ini mendukung penelitian Callister, R (2016) menyebutkan bahwa pembelajaran tatap muka memperoleh hasil belajar yang lebih tinggi dari pada pembelajaran online

2. Proses pelaksanaan pembelajaran secara jarak jauh ataupun daring yang belangsung pada peserta didik kelas $X$ IPA SMA Santa Maria Kabanjahe yang belajar dari rumah mereka masing-masing juga dapat berjalan dengan baik meskipun tidak sebaik pembelajaran luring. Hal ini dapat terjadi karena pembelajaran PJOK yang dilakukan meskipun secara daring dapat diberikan dalam bentuk video pembelajaran yang di upload ke dalam aplikasi youtube begitu juga materi ajar dan juga tugas yang diberikan kepada peserta didik melalui aplikasi google classroom peserta didik merespon dan menanggapi dengan baik dalam bentuk komentar dalam video pembelajaran dan juga pengumpulan tugas yang diberikan. Sejalan dengan temuan Mustakim (2020) mengenai efektivitas pembelajaran daring menggunakan media online selama covid19, bahwa untuk meningkatkan kualitas pembelajaran daring selama pandemi covid-19, maka pemberian materi pembelajaran sebaiknya disampaikan mengirim materi dalam bentuk video untuk memudahkan peserta didik dalam memahai materi, dan memilih media berupa video dengan menggunakan bahasa yang mudah dipahami. Mendukung dengan temuan yang di kemukakan oleh Nguyen, T (2015) yang menyatakan bahwa pembelajaran online "cukup efektif" dan menyarankan untuk lebih dikembangkan agar dapat melampaui asumsi bahwa "tidak ada perbedaan yang signifikan.

3. Terdapat perbedaan hasil belajar peserta didik yang proses pembelajarannya baik secara luring begitu juga peserta didik yang pembelajarannya secara daring dari, yakni pembelajaran yang dilaksanakan secara tatap muka lebih efektif dibandingkan dengan pembelajaran yang dilaksanakan secara jarak jauh. Hal ini terjadi karena pembelajaran PJOK pada dasarnya adalah praktek dan dominan dengan aktivitas fisik secara langsung, dimana peserta didik yang berada di asrama yang belajar secara luring dapat secara langsung mempelajari dan aspek keterampilannya dapat langsung di evaluasi oleh tenaga pendidik. Seperti yang dikemukakan oleh Akbar J Awal (2016) Pembelajaran tatap muka (face to face) adalah kemampuan pengajar dalam mengevaluasi hasil belajar secara langsung sangat menentukan, dan penguasaan konsep materi pelajaran di lingkungan tempat belajar sedangkan peserta didik yang belajar dari rumah secara daring harus membiasakan diri dengan kebiasaan baru secara mandiri untuk belajar dan juga melatih keterampilan diri melalui video pembelajaran begitu juga materi yang disampaikan secara virtual. Mendukung juga penelitian yang disampaikan oleh Sinambela (2006:78) yaitu beberapa indikator keefektifan pembelajaran adalah ketercapaian ketuntasan belajar, ketercapaian keefektifan aktivitas siswa (yaitu pencapaian waktu ideal yang digunakan siswa untuk melakukan setiap kegiatan yang termuat dalam rencana pembelajaran), dan melihat ketercapaian efektivitas proses belajar mengajar dapat akan dapat dilihat dari nilai hasil belajar siswa.

\section{KESIMPULAN}

Berdasarkan hasil analisis data dan pembahasan dapat disimpulkan bahwa:

1. Proses pelaksanaan pembelajaran secara tatap muka atapun luring yang berlangsung pada peserta didik kelas $X$ IPA SMA Santa Maria Kabanjahe dapat 
meningkatkan hasil belajar PJOK dapat dilihat dari bukti laporan hasil belajar peserta didik semester ganjil dan berlangsung dengan efektif, karena pembelajaran PJOK yang dilakukan secara luring dapat diberikan secara langsung kepada peserta didik begitu juga dengan keterampilan psikomotorik peserta didik yang langsung dapat di evaluasi.

2. Proses pelaksanaan pembelajaran secara jarak jauh ataupun daring yang belangsung pada peserta didik kelas $X$ IPA SMA Santa Maria Kabanjahe yang belajar dari rumah mereka masingmasing juga dapat berjalan dengan baik meskipun tidak sebaik pembelajaran luring, karena dapat dilihat dari bukti laporan hasil belajar peserta didik semester ganjil, karena pembelajaran PJOK yang dilakukan meskipun secara daring dapat diberikan dalam bentuk video pembelajaran yang di upload ke dalam aplikasi youtube begitu juga materi ajar dan juga tugas yang diberikan kepada peserta didik melalui aplikasi google classroom peserta didik merespon dan menanggapi dengan baik dalam bentuk komentar dalam video pembelajaran dan juga pengumpulan tugas yang diberikan.

3. Terdapat perbedaan hasil belajar peserta didik dalam proses pembelajaran secara tatap muka yang dilaksanakan terhadap peserta didik yang berada di asrama kelas X IPA lebih efektif dibandingkan dengan proses pembelajaran yang dilaksanakan secara jarak jauh terhadap peserta didik yang belajar dari rumah kelas X IPA SMA Swasta Santa Maria Kabanjahe yang dapat dilihat dari laporan hasil belajar peserta didik semester ganjil tahun pelajaran 2020/2021.

\section{DAFTAR PUSTAKA}

Dimiyati dan Mudjiono. 2009. Belajar dan Pembelajaran. Jakarta : Rineka

\section{SARAN}

Berdasarkan kesimpulan diatas maka ada beberapa saran yang dapat peneliti sampaikan dan diberikan kepada pihak terkait. Saran-saran tersebut dipaparkan dalam penejelasan berikut ini antara lain:

1. Diharapkan kepada tenaga pendidik dan juga peserta didik yang berada di ruang lingkup SMA Swasta Santa Maria Kabanjahe yang proses belajar mengajar berlangsung secara tatap muka, agar tetap menjaga dan mematuhi protokol kesehatan sesuai anjuran pemerintah karena kita harus saling menjaga satu sama lain.

2. Meskipun dalam situasi pandemi covid-19 dan pembelajaran secara jarak jauh masih dilaksanakan, maka diharapkan peserta didik yang proses belajar mengajar berlangsung secara jarak jauh tetap semangat dalam melaksanakan pembelajaran, begitu juga tenaga pendidik agar lebih membuat kreatifitas dan animasi dalam proses pembelajaran agar peserta didik tetap semangat dan tidak merasa bosan dalam pembelajaran daring.

3. Situasi ini tidak dapat hanya ditanggung oleh tenaga pendidik dan juga peserta didik saja, namun juga kerjasama dari orang tua yang saling membimbing dan memberikan arahan juga motivasi kepada peserta didik agar tetap semangat dalam belajar.

4. Disarankan kepada peneliti lain yang berminat mengadakan penelitian lebih dalam terkait efektivitas pembelajaran secara tatap muka dan pembelajaran jarak jauh dapat menjadikan hasil penelitian ini sebagai salah satu referensi untuk meneliti dalam lingkup yang lebih luas, seiring dengan perkembangan zaman.

$\begin{array}{ccr}\text { Cipta } & \text { Gusti Sri, dkk. } & 2020 . \\ & \text { Pembelajaran } \quad \text { Daring } & \text { Di } \\ \text { Tengah Pandemi Covid } & 19 . \\ \text { Medan : Yayasan Kita Menulis. }\end{array}$ 
Kanca, I Nyoman. 2010. Metodologi

Penelitian Pengajaran Pendidikan Jasmani dan Olahraga. Singaraja: Universitas Pendidikan Ganesha

Kanca, I Nyoman \& Wijaya, Made Agus. 2018. Buku Aajar Paradigma Baru Pembelajaran PJOK.Singaraja Undiksha Press.

Kementrian Pendidikan dan Kebudayaan. 2017. Pendidikan Jasmani, Olahraga dan Kesehatan. Jakarta : Pusat Kurikulum dan Perbukuan.

Mashud, M. 2019. "Analisis Masalah Guru Pjok Dalam Mewujudkan Tujuan Kebugaran Jasmani. Multilateral Jurnal Pendidikan Jasmani Dan Olahraga", 17(2).

Mustakim. (2020). Efektivitas Pembelajaran Daring Menggunakan Media Online Selama Pandemi Covid19 pada Mata Pelajaran Matematika. http://jurnal.uinalauddin.ac.id/index.ph p/alasma/article/view/1364 6 diakses pada 23 Agustus 2020

Nguyen, T. (2015). The effectiveness of online learning: Beyond no significant difference and future horizons. MERLOT Journal of Online Learning and Teaching, 11(2), 309-319.

Pardomuan N.J.M. Sinambela, M. P. 2008. "Faktor-Faktor Penentu Keefektifan Pembelajaran Dalam Model Pembelajaran Berdasarkan Masalah (Problem Based Instruction)". Jurnal Generasi Kampus, Vol 1, No. 2.

Paturusi Achmad. 2012. Manajemen

Pendidikan Jasmani dan

Olahraga. Jakarta : Rineka Cipta

Prasetya, T. A., \& Harjanto, C. T. 2020. Pengaruh Mutu Pembelajaran Online Dan Tingkat Kepuasan Mahasiswa Terhadap Hasil Belajar Saat Pandemi Covid19. Pendidikan
Teknologi Dan Kejuruan, Vol 17, No. 2.

Purnama Sary Diah dan Panggung

Sutapa. 2020. "Efektivitas

Pembelajaran Jarak Jauh Dengan

Daring Selama Pandemi Covid 19

Mata Pelajaran PJOK. Universitas Negeri Semarang. Tersedia

http://semnas.univpgripalembang.a

c.id (diakses pada 20 Desember 2020)

Putra Angga. 2020. Implementasi Pembelajaran PJOK Pada Masa Pandemi Covid 19 Di SD Negeri Lendah Kabupaten Kulon Daerah Istimewa Yogyakarta. Universitas Negeri Yogyakarta. Tersedia http://journal.uny.ac.id/index.php/JJ P/article (diakses pada 24 Desember 2020).

Rusman. (2016). Pembelajar Tematik Terpadu. Jakarta: Rajagrafindo Persada

Sari, D. P., \& Sutapa, P. 2020. "Efektivitas Pembelajaran Jarak Jauh Dengan Daring Selama Pandemi Covid-19 Mata Pelajaran Pendidikan Jasmani Olahraga Dan Kesehatan (PJOK)". In Seminar Nasional Olahraga (Vol. 2, No. 1).

Sugiyono. 2013. Metode Penelitian Kuantitatif, Kualitatif Dan $R$ \& D. Bandung: Alfabeta.

Suharsaputra, Uhar. 2012. Metode Penelitian Kuantitatif, Kualitatif dan Tindakan. Bandung : Refika Aditama.

Suyono dan Hariyanto. 2015. Implementasi Belajar dan Pembelajaran. Bandung. : PT Remaja Rosdarkaya. 
JURNAL PENDIDIKAN JASMANI OLAHRAGA DAN KESEHATAN Volume 9 No 1, Edisi 2021 